\title{
Resources in academic discourse: An empirical investigation of management journals
}

\author{
Marko Seppänen, Saku Mäkinen \\ Tampere University of Technology (FINLAND) \\ marko.seppanen@,tut.fi; saku.makinen@,tut.fi
}

Received May 2009

Accepted March 2010

\begin{abstract}
Commonly shared conceptualizations of resources are scant in academic management research which strikes as somewhat peculiar since resources and their allocation thereof have long been recognised to be at the heart of the competitive advantage and performance of a firm. The research literature considering resources as basis for competitive advantages has further faced contemporary criticism for the vagueness of the fundamental definition of the resource concept. Therefore, this paper empirically studies the representation of resource concept in academic management research literature. The paper reports results on the state of conceptualisations of organisations' resources found in two distinct sources of research literature, namely ScienceDirect's database and ISI's top management journals, resulting in two data sets of a total of 457 articles. The findings illustrate the two-dimensional conceptual farrago in the conceptualisations; on the definitions of the resource concept itself and on the internal structure and the level of analysis when the concept is considered. In addition, the paper sheds light on the temporal evolution of the discourse explicitly considering resources. Finally, the paper considers several remedies for these deficiencies in order both to aid future theory development in management studies and to help increase the practical impact of the research in assisting managerial decision-making.
\end{abstract}

Keywords: resources, discourse, strategic management, category, competitive advantage 


\section{Introduction}

This paper addresses the questions of what and how resources have been used in management research literature. In management research resources have been widely accepted as main building blocks for many theories (e.g. resource-based theory, resource-advantage theory and resource-allocation theory) explaining various aspects of organisational behaviour and performance. Some researchers have suggested that resources can be arranged in a hierarchical fashion, building on resource-advantage theory's notion of basic resources and higher-order resources (Hunt, 2000; Madhavaram \& Hunt, 2008; Collis \& Montgomery, 1995; Fernández, Montes, \& Vázquez, 2000; Grant, 1991; Seppänen \& Mäkinen, 2007). For example, competences and capabilities are higher order resources in a sense that they are bundles of basic resources. Usually, existing categorisations are targeted to explore resources from particular perspectives, for instance, from perspectives of intellectual capital (e.g. Nahapiet \& Ghoshal, 1998) or business model (e.g. Seppänen \& Mäkinen, 2007). These categorisations are important for the development of theory in general, and hierarchical schemas are particularly important (Tuomi, 1999) since they bring structure and coordination to discourse of developments.

However, in recent literature criticism on the resource conceptualisations have been raised in tandem to these developments (a recent review e.g. Kraaijenbrink, Spender \& Groen, 2010). Namely, the fundamental, axiomatic definitions considering the conceptualisations of resource have been noted as too varied and all inclusive (e.g. Priem \& Butler, 2001a). Therefore, the purpose of this paper is to explore the current state of definitions of the resource concept in the management research field at large without concentrating on specific research streams. The paper investigates, how the heterogeneity of the definitions of the resource concept is manifested, if so at all, in the management research articles, both in general and in the top research journals.

For the purposes of this study, we use a framework recently proposed for classifying resource categories (Madhavaram \& Hunt, 2008). Reason for selecting this particular starting point is that it essentially includes most of the resources identified in the earlier research considering resource-based view (e.g. Wernefelt, 1984; Barney, 1991; Conner, 1991; Hall, 1992). This classification proposes that 
there exist three levels of resources: 1) basic, 2) composite, and 3) interconnected operant resources. Madhavaram \& Hunt (2008) did not, for some reason, provide a list for basic operant resources, but refer only to prior research's seven categories of resources. This list includes physical, financial, organizational, relational, human, informational, and legal resources that form the basic categories under which all other resources can be classified.

In this study, we populate a list of papers in the current management literature dealing with resource concepts. Based on two separate data sets, we show how the current discourse concerning the resource concepts in the field of management studies is distorted. Finally, we discuss the possibilities for further research, and provide suggestions on how the distortions might be remedied and research based on resource conceptualisations improved.

\section{Theoretical background}

Resources have gained abundance of attention in academic business research in recent decades. Resources have been acknowledged at the heart of the competitive advantage and performance of an entrepreneurial firm in creating new business by managing the firm and its innovations (Barney \& Clark, 2007; Foss, 1997; Foss, 2007; Hunt, 2000; Peteraf, 1993; Wernerfelt, 1984). In essence, the resourceadvantage theory combines heterogeneous demand theory with the resourcebased theory of the firm (Barney \& Clark, 2007; Hunt, 1997; Hunt, 2000). That is, intra-industry demand is viewed as significantly heterogeneous with respect to consumers' tastes and preferences, and firms are viewed as combiners of heterogeneous, imperfectly mobile entities that are labelled resources in order to fulfil customers' needs, wants, and preferences. Resources, in general conception, are considered as "any factor that contributes to the value generating processes of the company and is, more or less directly, under the control of the company itself" (Bontis, Dragonetti, Jacobsen, \& Roos, 1999, p. 397). Competition is viewed as a process that consists of the perpetual battle among firms for comparative advantages in utilizing resources that will yield marketplace positions with competitive advantage and, thereby, superior financial performance. Therefore, a firm's comparative advantage resulting from acquisition of, allocation of, and utilization of resources may enable it to achieve superior performance through a 
position of competitive advantage in some market segment(s) (Madhavaram \& Hunt, 2008).

The resource-based view (RBV) of the firm, originating from the seminal work of Wernerfelt (1984), is essentially concerned with competitive advantage, and with sustained competitive advantage in particular. A sustainable competitive advantage is understood as an ability of a company to generate above-normal economic rents, or profits, over a prolonged period of time. The resource-based view emphasizes the resources under the control of a company and the exploitation of these resources as an essential source of sustained competitive advantage (e.g. Barney, 1991). The central starting point in the resource-based view is that in a situation, where all competing companies are identical with respect to their resource-base, and where resources are perfectly mobile, achieving sustainable competitive advantage is not possible as a resource acquisition or utilization which results or is assumed to result in above-normal profits is rapidly nullified by the competitors. Extending from the above theoretical base, the standpoint of the resource-based view, in contrast, is that heterogeneity in companies' resources may explain sustained above-normal profitability (e.g. Peteraf, 1993).

A wide variety of the resources existing is briefly reviewed in the following. Wernerfelt (1984) identified seven types of resources: 1 . brand names, 2 . in-house knowledge of technology, 3. employment of skilled personnel, 4. trade contracts, 5. machinery, 6. efficient procedures, and 7. capital. It must be noted, however, that these resource categories are exemplary by their nature and contain no hierarchy. Chatterjee (1990), in turn, divided resources into physical and intangible resources. According to them physical resources encompass plants, equipment, land, and distribution channels whereas intangible resources contain resources such as marketing skills, innovating skills, and management know-how. This division of resources into physical and intangible was adopted also by Chatterjee and Wernerfelt (1991). They, however, identified different items under intangible assets, namely brand names and innovative capability. They also added a third resource type, financial resources, including internal and external funds.

Barney (1991) also included physical (capital) resources in his treatment, but subdivided intangible resources into human (capital) resources and organizational (capital) resources. The treatment of Conner (1991) is very similar but replaces 
organizational resources with reputational resources. The four categories of Barney (1991) and Conner (1991) were adopted also by Grant (1991), who suggested two additional resource types; financial and technological resources in addition to physical, human, organizational, and reputational resources. Very similar treatment was offered by Mahoney and Pandian (1992) according to whom resources can be categorized into financial resources, physical resources, human resources, organization resources, technological capabilities, and intangible resources. It is noteworthy, however, that the category "intangible resources" is independent of and at the same level than "human resources", for instance.

Further, Hall (1992) considers only intangible resources; patents, trademarks, copyright and registered design, contracts, trade secrets, reputation, and networks and intangible assets; skills: know-how, and culture. Similarly Schoenecker and Cooper (1998) recognize intangible resources of technological resources, marketing resources, and financial resources. Miller \& Shamsie (1996) outline resources to three categories i.e. property-based resources, knowledge-based resources, and contracts.

However, the use of resources in research, and the RBV especially, has been criticized on the expansive definitions of resource concepts and its success has been attributed, at least partially, to this vague definition (Denrell, Fang, \& Winter, 2003). The conception concerning the vagueness of a resource is not a new one (see e.g. Srivastava, Fahey, \& Christensen, 2001). In addition, the RBV has been also criticized on its inability to explain the isolating mechanisms that enable competitive advantage to be sustained and dynamic capabilities has been designed as an answer to this concern (e.g. Teece, Pisano \& Shuen, 1997). They define dynamic capabilities as “...firm's ability to integrate, build, and reconfigure internal and external competences to address rapidly changing environments". However, this and similar definitions have raised serious concerns, again, on the axiomatic definitions of the concepts since the capabilities and resources are more or less overlapping.

In order to shed light on the resource advantage theory and its main building blocks Madhavaram and Hunt (2008) proposed a hierarchy of operant resources which, at least partially, ties capabilities and resources together conceptually. Starting from the seven basic resource categories (financial, physical, legal, 
human, organizational, informational, and relational), they suggest basic, composite, and interconnected operant resources as the hierarchy. Basic level resources refer to building blocks for higher-order resources, and basic resources are such as skills and knowledge. Composite, operant resource (COR) is defined as "a combination of two or more distinct, basic resources, with low levels of interactivity, that collectively enable the firm to produce efficiently and/or effectively valued market offerings" (Madhavaram \& Hunt, 2008, p.70). Further, they argue that interconnected, operant resources (IOR) are similar to CORs, but they emphasize interactivity among its constituent, basic resources: "An IOR as a combination of two or more distinct, basic resources in which the lower order resources significantly interact, thereby reinforcing each other in enabling the firm to produce efficiently and/or effectively valued market offerings" (Madhavaram \& Hunt, 2008, p.70). As an example, they have identified some examples for extant literature to demonstrate what these higher-order resources (CORs and IORs) include. For instance, different types of capabilities (e.g. price-setting capability, customer response capability) belong to CORs whereas product innovation competence and knowledge creation capability are examples of IORs.

\section{Methodology}

Based on above, we may conclude that recent, contemporary research is seriously concerned with the fundamental definition of resource and is also seeking ways to tackle this issue. In response to this increasing attention to the fundamental conceptual issues surrounding the resource concept, we concentrate on the definitions of resources themselves rather than reviewing the RBV literature, since our aim is to look at the management research in general and the use of resource concepts in this research.

To study how the concept of resource is being used in contemporary research, we examined the occurrences of resource concepts in the academic management and business research literature. In an ontological sense, we argue that these concepts have established their meanings when they are used in the vocabulary of scientific journals, thus resulting in an established set of literary concepts to be included in our study. We aimed to collect representative data sets from two sources, namely from the general management journals as an exploration whether there may be a convergence found in general treatment of the resource concept. Further, in 
contrast, we similarly searched the top management research journals, representing the established scientific knowledge and its accumulation. The top management journals, measured by ISI's impact factor, aim to represent the most commonly shared set of resource concepts, as they have been considered to represent the highest scientific quality in the field. We are interested in studying whether these two data sets differ from one another, and if so, to what extent.

The first data set is based on ScienceDirect's database, the digital library of Reed Elsevier PLC. The data set covers all articles in the time span from the beginning of database (announced to be year 1823) to the end of 2008. In addition, we limited our search to the category of Business, Management, and Accounting. This category includes 946 journal titles. To acquire broad coverage on the topic, we started with the term "resource" anywhere in the article which returned more than 44,000 articles; searching only for abstracts returned over 5,400 articles. Therefore, we decided to use Madhavaram \& Hunt's (2008) definition for basic resources - due to its comprehensiveness in comparison to other similar categorizations - to narrow our search and employed seven different search terms. After several test searches, the final search term was "title (resource) and abstract (resource and (physical or financial or organizational or relational or human or informational or legal))." In this manner, our first data set comprised 349 articles.

The second data set aimed to reveal to what extent resource concepts exist in top management research journals, thus demonstrating how well established these concepts are in academic research. The data set includes articles from the ten top management journals following similar studies: MIS Quarterly, Academy of Management Review, Academy of Management Journal, Organization Science, Strategic Management Journal, Information Systems Research, Administrative Science Quarterly, Journal of International Business Studies, Information \& Management, and J ournal of Operations Management. The selection is based on ISI impact factor rankings for management journals in 2007. For this inquiry, we expanded our search to cover all years when each journal was published until the end of 2008. We kept the same search term as was with the first data set. Thus, the final second data set comprised 108 articles.

Our analysis of the data sets was carried out as follows. We treated the first data set essentially an exploratory phase of our research. The exploration intended to 
validate the antecedent of conceptual confusion in general usage of the resource concept in management research literature in general. We analyzed the titles and abstracts of the papers in order to receive a general understanding how resource concepts were used in the papers. For the second data set, we started analyses by extracting titles and abstracts of all articles. We used two researchers that independently searched the titles and abstracts, firstly to find one of the seven basic resource types and secondly, to identify any other resource types. This procedure was used to enable maximum possibilities to identify all different types of resources that have a presence in a paper's title or abstract.

\section{Results}

Table 1 shows the timeline of the articles in the first data set. There were 349 articles in 63 journals, earliest article published in 1969. Noteworthy is a fairly large variation between the years; however, in general the trend is ascending. Despite the fact that the number of articles published in these journals has increased, the share of articles dealing with resources has remained fairly same due to the increasing amount of issues published. Noteworthy is that the resource concept itself has established itself as a part of the academic research scene, maintaining its quantitative amount of output. Therefore, resource concept is, indeed, valuable part of the research and it is used frequently in management studies.

In closer examinations, we also identified that two-thirds of articles were explicitly citing resource types which cannot be identified as any of the seven basic resource categories. The articles cited various types of resource like time was mentioned as a customer's resource, or similarly quality of technology and quality of established business connections were included as resources. Therefore, based on the diverse usage of various conceptualisations of resource concept, we concluded that the exploratory phase of our study concerning the first data set validated the contemporary hypothesis of the confusion in the usage of the resource concept in the management literature at large. This strikes us as somewhat peculiar since a concept that has kept its pace in remaining on usage in research articles should have gained more established groundings. As a result, we continued towards the established, top level management journals to see how the resource concept has been used and whether we find convergence of the usage of the concept. 
Table 2 shows the timeline of the articles in the second data set. There were 108 articles in the selected ten top management journals. Interestingly, the trend has been descending during recent years, thus probably denoting that the focus of top management journals has been moving elsewhere from the resource discussions.

\begin{tabular}{|c|c|c|c|c|c|c|c|c|c|c|c|c|c|c|c|c|c|c|c|c|}
\hline Journal title & 1969 & 1971 & 1972 & 1973 & 1974 & 1976 & 1977 & 1978 & 1979 & 1980 & 1981 & 1982 & 1983 & 1984 & 1985 & 1986 & 1987 & 1988 & 1989 & 1990 \\
\hline \multicolumn{21}{|l|}{ Human Resource Management Review } \\
\hline European Management Journal & & & & & & & & & & & & & & & & & 1 & & 2 & \\
\hline Accounting, Organizations and Society & & & & & & 9 & 3 & & & & & & & 1 & & & & 1 & 1 & \\
\hline \multicolumn{21}{|l|}{ Journal of Management } \\
\hline Journal of Business Research & & & & & & & & & & & & & & & & 1 & & & & \\
\hline \multicolumn{21}{|l|}{ International Journal of Hospitality Management } \\
\hline International Journal of Project Management & & & & & & & & & & & & & & & & & 2 & 1 & & \\
\hline \multicolumn{21}{|l|}{ Journal of Business Venturing } \\
\hline \multicolumn{21}{|l|}{ Journal of World Business } \\
\hline Long range planning & & & & & & & & 1 & & & & & & & & & & 2 & 1 & 1 \\
\hline \multicolumn{21}{|l|}{ Tourism Management } \\
\hline Information \& Management & & & & & & & & & & & & & & & & & & 3 & 1 & 1 \\
\hline Business horizons & 2 & & 1 & 1 & & & & & & & & & & 2 & & & & & & \\
\hline Journal of Operations Management & & & & & & & & & & & & & & 1 & & & & & & \\
\hline Socio-economic planning sciences & & 1 & & & & & & 1 & & & & & & 1 & & & & 1 & & \\
\hline The Journal of High Technology Management & & & & & & & & & & & & & & & & & & & & \\
\hline International Journal of Information Managemen & & & & & & & & & & & & & & & & & & & & \\
\hline Omega & & & & & 1 & & & & & & 1 & & 1 & & & & & 1 & & 1 \\
\hline Technological Forecasting and Social Change & & & & & & & & & & & & & & 1 & 1 & 1 & 1 & & & \\
\hline Industrial Marketing Management & & & & & & & & & & & & & & & & & & 1 & & \\
\hline Technovation & & & & & & & & & & & & & & & & & & & & \\
\hline Journal of Engineering and Technology Manage & & & & & & & & & & & & & & & & & & & & \\
\hline Journal of Quality Management & & & & & & & & & & & & & & & & & & & & \\
\hline Safety Science & & & & & & & & & & & & & & & & & & & & \\
\hline International Business Review & & & & & & & & & & & & & & & & & & & & \\
\hline Journal of vocational behavior & & & & & & & & & & & & & & & & & & & & \\
\hline International Journal of Accounting Information S & & & & & & & & & & & & & & & & & & & & \\
\hline The Cornell hotel and restaurant administration & & & & & & & & & & & & & & & & & & & & \\
\hline Journal of Retailing and Consumer Services & & & & & & & & & & & & & & & & & & & & \\
\hline Futures & & & & & & & & & & & & & & & & 1 & & & & 1 \\
\hline Decision Support Systems & & & & & & & & & & & & & & & & & & & & \\
\hline Utilities Policy & & & & & & & & & & & & & & & & & & & & \\
\hline Telecommunications Policy & & & & & & & & & 1 & & 1 & & & & & & & & & \\
\hline International Journal of Intercultural Relations & & & & & & & & & & 1 & & & & & & & & & & \\
\hline The British Accounting Review & & & & & & & & & & & & & & & & & & & & \\
\hline Journal of Accounting and Public Policy & & & & & & & & & & & & & 1 & & & & & & & \\
\hline Sport Management Review & & & & & & & & & & & & & & & & & & & & \\
\hline Scandinavian Journal of Management & & & & & & & & & & & & & & & & & & & & \\
\hline Applied Geography & & & & & & & & & & & & & 1 & & & & & & 1 & \\
\hline Research Policy & & & & & & & & & & & & & & & & & & & & \\
\hline The Leadership Quarterly & & & & & & & & & & & & & & & & & & & & \\
\hline The Journal of Strategic Information Systems & & & & & & & & & & & & & & & & & & & & \\
\hline Information Systems & & & & & & & & & & & & 1 & & & & & & & & \\
\hline Information and Organization & & & & & & & & & & & & & & & & & & & & \\
\hline Technology in Society & & & & & & & & & & & & & & & & & & & & \\
\hline Journal of Purchasing and Supply Management & & & & & & & & & & & & & & & & & & & & \\
\hline Journal of International Management & & & & & & & & & & & & & & & & & & & & \\
\hline Annals of Tourism Research & & & & & & & & & & & & & & & & & & & & \\
\hline Journal of Financial Economics & & & & & & & & & & & & & & & & & & & & \\
\hline The Columbia Journal of World Business & & & & & & & & & & & & & & & & & & & & \\
\hline Journal of Air Transport Management & & & & & & & & & & & & & & & & & & & & \\
\hline Public Relations Review & & & & & & & & & & & & & & & & & & & & \\
\hline Emerging Markets Review & & & & & & & & & & & & & & & & & & & & \\
\hline Journal of Accounting Education & & & & & & & & & & & & & & & & & & & & \\
\hline Critical Perspectives on Accounting & & & & & & & & & & & & & & & & & & & & \\
\hline Management Accounting Research & & & & & & & & & & & & & & & & & & & & \\
\hline Journal of Retailing & & & & & & & & & & & & & & & & & & & & \\
\hline Organizational behavior and human decision pro & & & & & & & & & & & & & & & & & & & & \\
\hline Journal of Economic Behavior \& Organization & & & & & & & & & & & & & & & & & & & 1 & \\
\hline Research in Organizational Behavior & & & & & & & & & & & & & & & & & & & & \\
\hline Journal of Economic Psychology & & & & & & & & & & & & & & & & & & & & \\
\hline Journal of economics and business & & & & & & & & & & & & & & & & & & & & \\
\hline International Journal of Research in Marketing & & & & & & & & & & & & & & & 1 & & & & & \\
\hline Total & 2 & 1 & 1 & 1 & 1 & 9 & 3 & 2 & 1 & 1 & 2 & 1 & 3 & 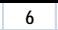 & 2 & 3 & 4 & 10 & 7 & 4 \\
\hline
\end{tabular}

Table 1 (1/2). "Temporal evolution of resource discussion in the first data set". 


\begin{tabular}{|c|c|c|c|c|c|c|c|c|c|c|c|c|c|c|c|c|c|c|c|}
\hline Journal title & 1991 & 1992 & 1993 & 1994 & 1995 & 1996 & 1997 & 1998 & 1999 & 2000 & 2001 & 2002 & 2003 & 2004 & 2005 & 2006 & 2007 & 2008 & Total \\
\hline Human Resource Management Review & 5 & 2 & & 2 & & 2 & 2 & 7 & & 3 & 7 & 2 & 3 & 5 & 4 & 4 & 4 & 3 & 55 \\
\hline European Management Journal & 1 & 3 & & & 3 & 1 & & 3 & 3 & & & & & & & 3 & & & 20 \\
\hline Accounting, Organizations and Society & & & & & & & & & & & & & & & 3 & 1 & & & 19 \\
\hline Journal of Management & & & 1 & 2 & 1 & & 1 & 3 & 1 & 1 & 3 & 1 & 2 & 1 & & & & & 17 \\
\hline Journal of Business Research & & & & 1 & 1 & & & & & & 2 & & 1 & 2 & 3 & 1 & & 1 & 13 \\
\hline International Journal of Hospitality Management & & & 1 & 1 & & & & 1 & 1 & & 1 & & & 2 & & 3 & 2 & 1 & 13 \\
\hline International Journal of Project Management & & 1 & & & & & & 1 & & & & & 1 & 1 & 1 & & 1 & 2 & 11 \\
\hline Journal of Business Venturing & & & & 1 & & & 1 & & 2 & & 2 & & & & 2 & 1 & 1 & 1 & 11 \\
\hline Journal of World Business & & & & & & & 1 & & 1 & & 1 & & & 3 & & & 2 & 1 & 9 \\
\hline Long range planning & 1 & & & & & & 1 & 1 & & & & & & & & & & & 8 \\
\hline Tourism Management & & & & 3 & & & & 1 & 1 & & 1 & & & & & & 2 & & 8 \\
\hline Information \& Management & & & & 1 & & & & & & & & & & & & 1 & 1 & & 8 \\
\hline Business horizons & & & & & & & & & & & & & & & & & 1 & 1 & 8 \\
\hline Journal of Operations Management & 1 & & & & & & & & 1 & & & & 2 & & & & 2 & 1 & 8 \\
\hline Socio-economic planning sciences & & & & & & 1 & 1 & & & & & & & & & & 1 & & 7 \\
\hline The Journal of High Technology Management Research & & & & & 1 & & 1 & & 1 & & 1 & & & & & & 1 & 2 & 7 \\
\hline International Journal of Information Management & 1 & & & 1 & & & 1 & & & & & & & & & 1 & 1 & 1 & 6 \\
\hline Omega & & & & & & & & & & & & & 1 & & & & & & 6 \\
\hline Technological Forecasting and Social Change & & & & & & & & & & & & & & & 1 & & 1 & & 6 \\
\hline Industrial Marketing Management & & & & & & & & & & & & 1 & 1 & & 1 & 1 & & 1 & 6 \\
\hline Technovation & & & & & & 1 & & & & 2 & & 1 & & & & 1 & & & 5 \\
\hline Journal of Engineering and Technology Management & & & & & & 1 & & 1 & & 1 & & & & 1 & & & 1 & & 5 \\
\hline Journal of Quality Management & & & & & & 2 & & & 1 & 1 & & & & & & & & & 4 \\
\hline Safety Science & & & & & & & & & & 2 & & & 2 & & & & & & 4 \\
\hline International Business Review & & & & & & & 1 & & & 1 & & 1 & 1 & & & & & & 4 \\
\hline Journal of vocational behavior & & & & & & & 1 & & 1 & & & & 2 & & & & & & 4 \\
\hline International Journal of Accounting Information Systems & & & & & & & & & & & & & 1 & & 1 & & 1 & 1 & 4 \\
\hline The Cornell hotel and restaurant administration quarterly & & & & & 1 & 1 & & & & 1 & & 1 & & & & & & & 4 \\
\hline Journal of Retailing and Consumer Services & & & & & & 1 & & 1 & & & & & & & & 2 & & & 4 \\
\hline Futures & 1 & & & 1 & & & & & & & & & & & & & & & 4 \\
\hline Decision Support Systems & & & & & 1 & & & 1 & & & 1 & & & & & & 1 & & 4 \\
\hline Utilities Policy & 1 & 1 & & & 1 & & & & & 1 & & & & & & & & & 4 \\
\hline Telecommunications Policy & & & & 1 & & & & & & & & & & & & & & & 3 \\
\hline International Journal of Intercultural Relations & & & & & & & 1 & & & & & & & & 1 & & & & 3 \\
\hline The British Accounting Review & & & & & & & & & & 1 & & 1 & & & & & 1 & & 3 \\
\hline Journal of Accounting and Public Policy & & & & & & & & 1 & & & 1 & & & & & & & & 3 \\
\hline Sport Management Review & & & & & & & & 1 & & & & & & & & 2 & & & 3 \\
\hline Scandinavian Journal of Management & & & & & & & & 1 & & & & & 1 & & & & & 1 & 3 \\
\hline Applied Geography & & & 1 & & & & & & & & & & & & & & & & 3 \\
\hline Research Policy & & & & & & & & & 1 & & & & & & 1 & & & & 2 \\
\hline The Leadership Quarterly & & & & & & & & & & & & & & 1 & 1 & & & & 2 \\
\hline The Journal of Strategic Information Systems & & & & & & & & & & 1 & & & 1 & & & & & & 2 \\
\hline Information Systems & & & & & & & & & & & 1 & & & & & & & & 2 \\
\hline Information and Organization & & & & & & & & & & & & & 2 & & & & & & 2 \\
\hline Technologyin Society & & & & & & & & & & & & & & & & 1 & & 1 & 2 \\
\hline Journal of Purchasing and Supply Management & & & & & & & & & & & & & & & & & & 2 & 2 \\
\hline Journal of International Management & & & & & & & & & & & & & & 1 & & & & 1 & 2 \\
\hline Annals of Tourism Research & & & & & & & & & & & & & & & 1 & & & & 1 \\
\hline Journal of Financial Economics & & & & & & & & & & & & & & & 1 & & & & 1 \\
\hline The Columbia Journal of World Business & & & & & 1 & & & & & & & & & & & & & & 1 \\
\hline Journal of Air Transport Management & & & & & & & & & & & & & & & & 1 & & & 1 \\
\hline Public Relations Review & & & & & & & & & & & & & & & & 1 & & & 1 \\
\hline Emerging Markets Review & & & & & & & & & & & & 1 & & & & & & & 1 \\
\hline Journal of Accounting Education & & & & & & & & & & & & 1 & & & & & & & 1 \\
\hline Critical Perspectives on Accounting & & & & & & & & & & & & & & & & 1 & & & 1 \\
\hline Management Accounting Research & & & & & & & & & & & & & & 1 & & & & & 1 \\
\hline Journal of Retailing & & & & & & & & & & & & & & & & & & 1 & 1 \\
\hline Organizational behavior and human decision processes & & & & 1 & & & & & & & & & & & & & & & 1 \\
\hline Journal of Economic Behavior \& Organization & & & & & & & & & & & & & & & & & & & 1 \\
\hline Research in Organizational Behavior & & & & & & & & & & & & 1 & & & & & & & 1 \\
\hline Journal of Economic Psychology & & & & & & & & & & & & & & & & & 1 & & 1 \\
\hline Journal of economics and business & & & & & & & & & & & & & & & & & & 1 & 1 \\
\hline International Journal of Research in Marketing & & & & & & & & & & & & & & & & & & & 1 \\
\hline Total & 11 & 7 & 3 & 15 & 10 & 10 & 12 & 23 & 14 & 15 & 21 & 11 & 21 & 18 & 21 & 25 & 25 & 23 & 349 \\
\hline
\end{tabular}

Table $1(2 / 2)$. "Temporal evolution of resource discussion in the first data set". 


\begin{tabular}{|c|c|c|c|c|c|c|c|c|c|c|c|}
\hline YEAR & $\begin{array}{c}\text { Academy of } \\
\begin{array}{c}\text { Management } \\
\text { Journal }\end{array}\end{array}$ & $\begin{array}{c}\text { Academy of } \\
\text { Management } \\
\text { Review }\end{array}$ & $\begin{array}{c}\text { Strategic } \\
\text { Management } \\
\text { Journal }\end{array}$ & \begin{tabular}{|} 
Journal of \\
International \\
Business \\
Studies
\end{tabular} & $\begin{array}{c}\text { Administrative } \\
\text { Science } \\
\text { Quarterly }\end{array}$ & $\begin{array}{l}\text { Information \& } \\
\text { Management }\end{array}$ & $\begin{array}{c}\text { Journal of } \\
\text { Operations } \\
\text { Management }\end{array}$ & $\begin{array}{l}\text { Organization } \\
\text { Science }\end{array}$ & $\begin{array}{c}\text { MIS } \\
\text { Quarterly }\end{array}$ & $\begin{array}{c}\text { Information } \\
\text { Systems } \\
\text { Research }\end{array}$ & Total \\
\hline 1969 & & & & & & & & & & & 0 \\
\hline 1970 & & & & & & & & & & & 0 \\
\hline 1971 & & & & & & & & & & & 0 \\
\hline 1972 & & & & & & & & & & & 0 \\
\hline 1973 & & & & & & & & & & & 0 \\
\hline 1974 & & & & & & & & & & & 0 \\
\hline 1975 & & & & & & & & & & & 0 \\
\hline 1976 & & 1 & & & 1 & & & & & & 2 \\
\hline 1977 & & 1 & & & & & & & & & 1 \\
\hline 1978 & 1 & & & & & & & & & & 1 \\
\hline 1979 & & & & & & & & & & & 0 \\
\hline 1980 & & 1 & & & & & & & & & 1 \\
\hline 1981 & & & & & & & & & & & 0 \\
\hline 1982 & & & & & & & & & & & 0 \\
\hline 1983 & & 1 & 1 & & & & & & & & 2 \\
\hline 1984 & & 1 & & 1 & & & 1 & & & & 3 \\
\hline 1985 & & & & & 2 & & & & & & 2 \\
\hline 1986 & & 1 & & & & 1 & & & 1 & & 3 \\
\hline 1987 & & 1 & 1 & & & & & & & & 2 \\
\hline 1988 & & 2 & & & 2 & 2 & & & 1 & & 7 \\
\hline 1989 & & & & 1 & & 1 & & & & & 2 \\
\hline 1990 & & & & & 1 & 1 & & & & & 2 \\
\hline 1991 & 1 & 1 & 2 & & & & 1 & & & & 5 \\
\hline 1992 & 3 & & 1 & 1 & & & & 1 & & & 6 \\
\hline 1993 & 1 & 2 & & & & & & & & & 3 \\
\hline 1994 & 1 & 1 & & 1 & & 1 & & 1 & & & 5 \\
\hline 1995 & 1 & & 1 & 3 & & & & & & & 5 \\
\hline 1996 & 6 & 2 & 1 & & & & & 2 & & & 11 \\
\hline 1997 & 1 & 1 & 1 & & & & & & & & 3 \\
\hline 1998 & 1 & 2 & 1 & & 1 & 1 & & & & & 6 \\
\hline 1999 & 1 & 1 & 2 & & 1 & & 1 & 1 & & & 7 \\
\hline 2000 & 4 & & & & & & & & 2 & & 6 \\
\hline 2001 & 2 & & 3 & 1 & & & & & & & 6 \\
\hline 2002 & 2 & & & & & & & & & & 2 \\
\hline 2003 & & & 1 & 2 & & & 2 & 1 & & & 6 \\
\hline 2004 & & 1 & 1 & & & & & & & & 2 \\
\hline 2005 & & & & & 1 & & & & & 1 & 2 \\
\hline 2006 & & & & & & 1 & & & & & 1 \\
\hline 2007 & & & & & & 1 & 2 & & & & 3 \\
\hline 2008 & & & & & & & 1 & & & & 1 \\
\hline Total & 25 & 20 & 16 & 10 & 9 & 9 & 8 & 6 & 4 & 1 & 108 \\
\hline
\end{tabular}

Table 2. "Distribution in time of articles in the second data set".

Fig. 1 presents the amount of the seven basic resource types we found in 108 articles of top management research journals. We found three articles citing informational resources and 55 articles citing human resources in their title, while other of the seven basic resource types were missing. Similarly, four articles cited financial, 60 cited human, and one cited informational resources in their abstracts. This overwhelming dominance of the human resource was rather surprising. 


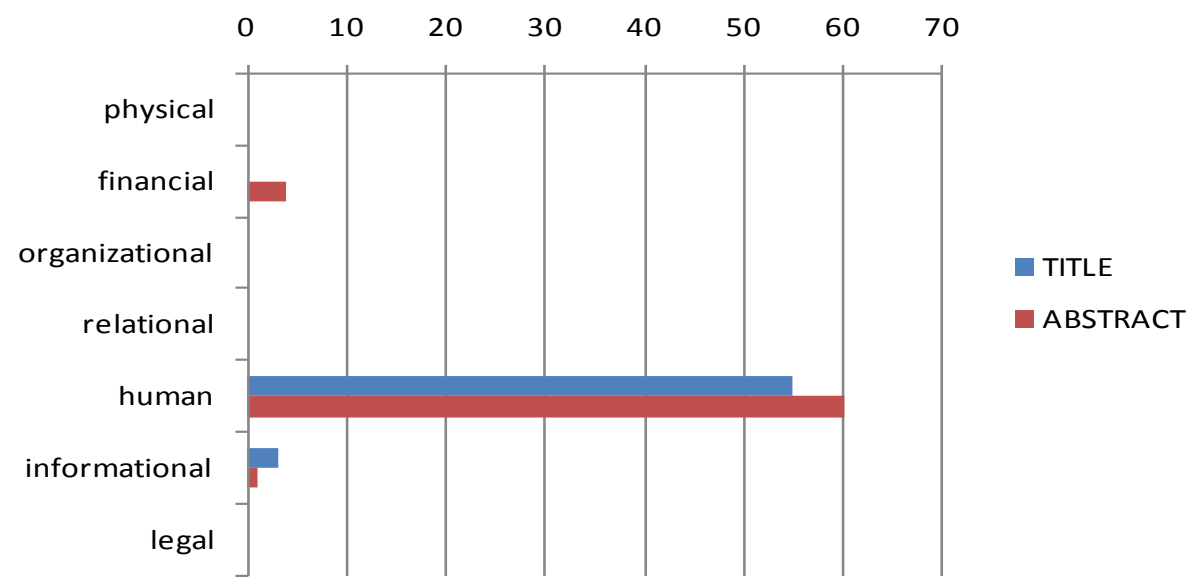

Figure 1. "The seven main resource categories manifested in titles and abstracts in the second data set".

Next, we exhibit the results concerning the presence of other resource conceptualisations in the top management journals, besides the seven basic resource types. In Fig. 2, the resource concepts are represented appearing in more than one top management research articles in our second data set.

Altogether, we found 157 different resources that were mentioned in 83 papers out of the 108 in our second data set. Further, if we look at how resources were treated we find that only six resource concepts ( $\sim 4 \%$ of the total 157$)$ were used more than twice and only 18 more than once $(\sim 11 \%$ of the total 157$)$ in the abstracts of the articles. Therefore, we find that a similar farrago in the axiomatic definition of the resource concept also persists in the top management research literature as was found in the general management research.

In summary of the above, we may conclude that resource, as a concept, has been defined in various ways and its coherent usage across the management research has been missing. Namely, very few basic resource items have established themselves to a degree that they would be shared among researchers. In particular, we find two ways in which the current conceptualisation of the resource concept is ambiguous. Firstly, the resource conceptualisation, in itself, remains an evasive in its axiomatic definition and particularly in conceptual clarity of types of resources considered. Secondly, tackling the level of analysis (we find CORs and IORs as well as basic resources cited as merely resources) in a hierarchical, meaningful sense, is missing the management research literature. 


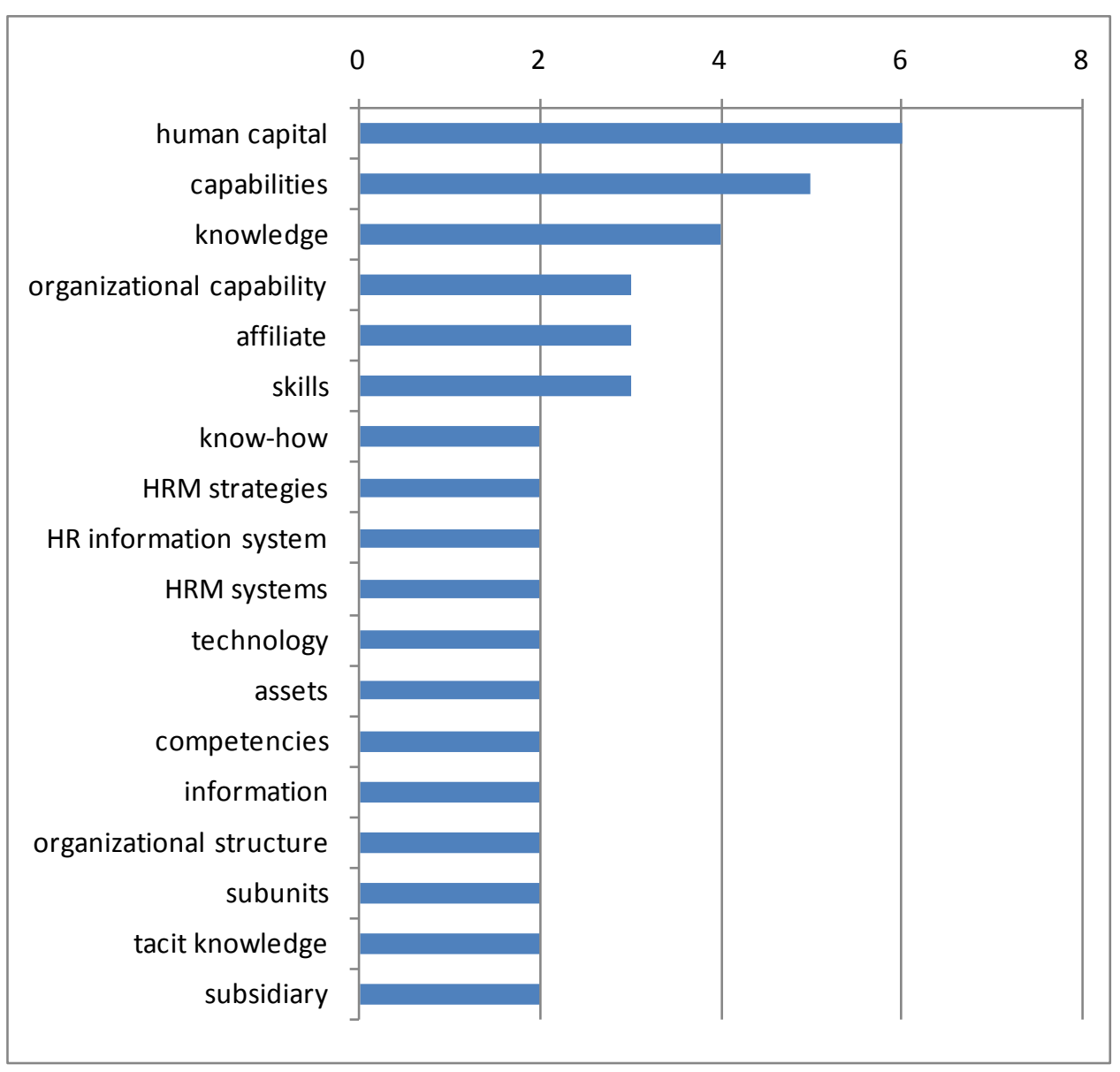

Figure 2. "The other resource types identified which were represented more than once in the abstracts in the second data set".

\section{Discussion}

Our research complements earlier research in that there is no previous attempt in the literature to identify and analyse resource concepts based on extensive analysis of the content of the whole database. Several more focused attempts have been carried out, but most of them were concentrated on higher-order resources (e.g. Hunt, 2000; Danneels, 2002), not on low-order, basic resources. This study seeks to start a search for rigour in fundamental definitions of resource as a scientific concept, as development of sound theory requires meticulously defined concepts. In addition, most importantly, the communication of research results remains skewed and arbitrary if the results of research are based on vague and ill-defined concepts. It has been proposed that concepts should be defined by minimising 
losses in connotation (depth) and concurrently retaining extensional (breadth) gains (Osigweh, 1989).

As we may see from the farrago of even basic resource concepts, the current abstraction of the concept has not yet reached a balance between definitional depth and breadth. This conceptual farrago may be a partial explanation for the past debate about the tautological nature of the resource-based view (Barney, 2001; Priem \& Butler, 2001a; Priem \& Butler, 2001b), where ability of resources as explaining a firm's competitive advantage was challenged. Only recently, it has been acknowledged that resource-based theory may not be, after all, tautological (Barney \& Clark, 2007, p. 253).

Since very few basic resource items have established themselves to a degree that they would be shared among researchers, the accumulation of scientific knowledge is missing in management research based on this concept. It becomes increasingly difficult to replicate research when conceptualisations are this varied and not shared. Also, building on existing knowledge and earlier literature becomes complicated. As a result, this might partly explain why the number of articles considering resources in the title or abstract of the top management journals has been descending. Of course, there might be other reasons as well, but creating coherently structured research based on ill-defined concepts becomes increasingly hard as the amount of research increases in the field.

Next, we found that in several papers the terms "asset", "resource", "capability" and even "competence" were used as synonyms. Because English is the mother tongue for a minority of people producing scientific outcomes in contemporary academic global community, exact semantics between the terms is probably not so evident. Similarly, English is not the same language everywhere in the world. Therefore, we also compare definitions provided by several dictionaries for how these key terms are defined. We used four dictionaries: Merriam-Webster, Collins Cobuild, the Oxford English Dictionary, and Bartleby's American Heritage. The following Figure 3 represents the relationships between the terms. The arrow shows the direction of relationship; for instance, "capability" was mentioned as a synonym for "resource" in two dictionaries (Collins and Oxford), but not vice versa. "Capability" and "competence" were considered to be synonyms in both directions in Collins and in Bartleby, but were not mentioned at all in Merriam-Webster or the 
Oxford. Finally, the terms "asset" and "resource" had several interrelationships but not a complete relationship.

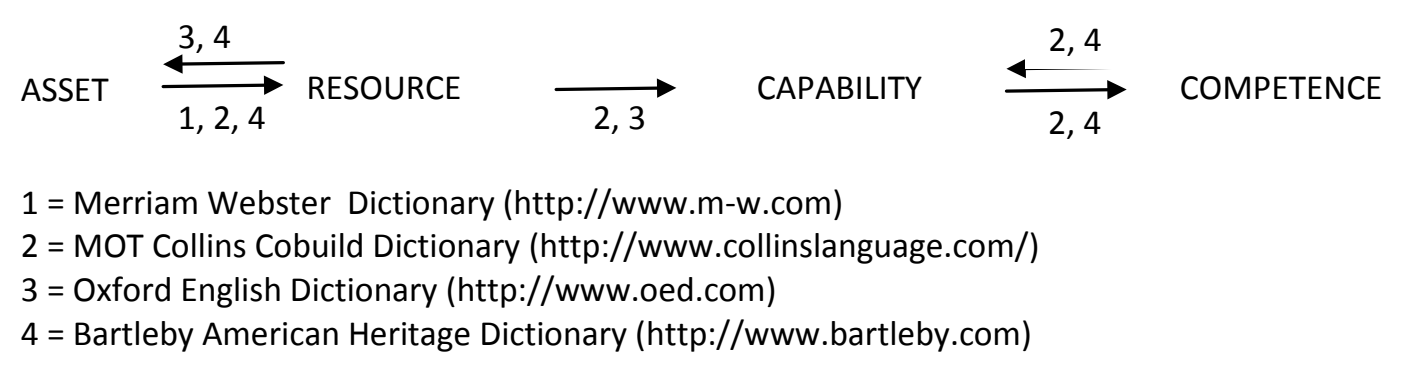

Figure 3. "Dictionary definitions of key terms: Arrows represent the direction of synonymous relationships".

This notion might reveal a bit about the sources in our discourse discrepancies and has some support on literature where assets and resources are interrelated. However, this relationship is not complete because in the literature resources are defined both tangible and intangible whereas assets are particularly allocated into tangible resources. However, capabilities and competences are in many cases considered synonymous (see Teece et al., 1997; Teece \& Pisano, 1994) even though, by definition, they differ in their use from one another. In addition, this interpretation may be interpreted in a way that assets lead to resources at general to be acquired, and allocation leads to some forms of capability, for better or worse, and in a comparison to competition this may lead to competence, again for better or worse vis a vis competitors. This interpretation of asset-resourcecapability-competence lends also partial support from the existing literature when capabilities are defined as "processes to integrate, reconfigure, gain, and release resource" (Eisenhardt \& Martin, 2000); thereby this type of distinction might bring, at least, partial clarity to the resource concept as well.

The study has several limitations. Firstly, ScienceDirect's database as a source of information may be only a partial representative to the issue under study. Therefore, further research may enlarge its coverage to other scientific databases such as ABI, IEEE Xplore, EBSCOhost, and Emerald. This will extend the data set to cover relevant business management literature addressing resource concepts in the management literature. 
In addition, the method includes several possible sources of bias and errors. Concerning the data sets, we have limited our searches by using previously identified types of resources that may have concurrently created some unidentified gaps in our data set. Moreover, investigating articles visually (that is, reading through) includes the possibility of human error, which could be eliminated by automated inspection. However, because this study was essentially an exploratory study, in the sense that the investigation method was refined during the research process, the automated process cannot include a similar flexibility. We may thus argue that our choice has been justified for the purposes of this study. Even though the analysis was restricted to clearly express resource concepts, only humans would be able to identify hidden connotations and use of words in order to prevent conceptual misunderstanding. Using automated search for finding resource concepts in top management journal papers may result in some papers that do not belong in the data set under closer examination. However, this is likely to produce only minor distortions in our data sets due to the relatively large number of papers $(n=457)$.

Time span is a potential source of bias, since the resource-based theory has its roots in the 1960s. Although we covered as long time span as possible for both data sets, the availability of data especially concerning early years is likely to cause some bias to the results. However, as language redefines itself continuously, we may argue that the results provide sufficient coverage and view to a conceptual state of affairs.

\section{Conclusion}

The purpose of this paper was to investigate whether there is heterogeneity in the definitions of the resource concept in the management research articles, both in general and in the top research journals. The paper has shown that that resource, as a concept, has been defined in various ways across the management research and its coherent usage has been missing. In particular, we find two ways in which the current conceptualisation of the resource concept is unclear and imprecise. Firstly, the resource conceptualisation, in itself, remains an evasive in its axiomatic definition. This has led the research reports to anecdotally cite some possible resources but not to define the concept rigorously. Secondly, conceptual handling of the resource concept that would be taking into account the internal structure of 
the concept and tackling the level of analysis in a hierarchical, meaningful sense is missing in the management research literature. Therefore, we did not find a shared conceptual definition of the resource concept that would be used when research is reporting about basic resources.

In addition the paper reports that the number of articles that explicitly dealt with the resource concepts was surprisingly small compared to the overall number of articles in the investigated database and the top management journals. In addition to the confusion in the conceptual development, this strikes us as somewhat odd since resources are currently important building blocks in many theories such as resource-based theory, resource-advantage theory, and resource-allocation theory. Although theories are being built upon resources, it is intriguing that the conceptualisation of the basic concept is still in progress.

In order to remedy the found deficiencies future research should be targeted toward developing rigorous axiomatic definitions of the resource concepts. This would fundamentally help in researchers using the same concept in their analyses. Also the conceptual analysis of the resource concept should be carried forward in order to shed light on the internal structure of the concept i.e. what it consists of and what not. This might be best approached in some hierarchical approach that also includes capabilities and competences in the analysis. In addition, empirical categorisations of the basic resources that have a better fit with the concepts manifested in the extant research should be explored. This would, at minimal level, give scientific community a taxonomy or list of basic resources that might be included when research on resources is prepared. Finally, we would call for a critical and rigorous development of criteria to identify resource concepts and their internal schemas.

From the managerial point of view, the implications of this study are two-fold. Firstly, understanding the varied nature of the resource concepts used in the literature guides in cautiously and also meticulously interpreting the results and suggestions provided by the research. Secondly, conceptual confusion may exist at the general level of resource concept but at the same time this creates a fruitful avenue for new ideas and also presents new resource concepts to the scientific and practicing community. Therefore, the research results may prove to be very practical, even though conceptual farrago still exists. From the practitioners' 
viewpoint, researchers' output might be difficult to perceive if conceptual clarity is missing. Therefore, this notion also paves the way for scholars by expressing the need to clarify basic concepts.

\section{Acknowledgements}

We would like to thank two anonymous reviewers of this journal for their constructive and helpful suggestions. Also, we are grateful for comments on earlier draft of the paper to the participants of the $4^{\text {th }}$ International Conference on Management of Innovation and Technology, 2008. Furthermore, we would like to thank MA Veikka Pirhonen for help in the data gathering phase of this study.

\section{References}

Abrahamson, E., \& Fairchild, G. (1999). Management fashion: lifecycles, triggers, and collective learning processes. Administrative Science Quarterly, 44(4), 708740. doi: $10.2307 / 2667053$

Barney, J. (1991). Firm resources and sustained competitive advantage. Journal of Management, 17(1), 99-120. doi: 10.1177/014920639101700108

Barney, J. (2001). Is the resource-based "view" a useful perspective for strategic management research? Yes. Academy of Management Review, 26(1), 41-56. doi: $10.2307 / 259393$

Barney, J., \& Clark, D. N. (2007). Resource-based theory. Creating and sustaining competitive advantage. New York: Oxford University Press.

Bontis, N., Dragonetti, N. C., Jacobsen, K., \& Roos, G. (1999). The knowledge toolbox: A review of the tools available to measure and manage intangible resources. European Management Journal, 17(4), 391-402.

doi: 10.1016/S0263-2373(99)00019-5

Collis, D. J., \& Montgomery, C. A. (1995). Competing on resources: Strategy in the 1990s. Harvard Business Review, 73(4), 118-129.

Chatterjee, S. (1990). Excess Resources, Utilization Costs, and Mode of Entry. The Academy of Management J ournal, 33(4), 780-800. doi: 10.2307/256290 
Chatterjee, S., \& Wernerfelt, B. (1991). The Link between Resources and Type of Diversification: Theory and Evidence. Strategic Management Journal, 12(1), 3348. doi: $10.1002 / \mathrm{smj} .4250120104$

Conner, C. R. (1991). A historical comparison of resource-based theory and five schools of thought within industrial organization economics: Do we have a new theory of the firm. Journal of Management, 17(1), 121-154.

doi: $10.1177 / 014920639101700109$

Danneels, E. (2002). The dynamics of product innovation and firm competences. Strategic Management J ournal, 23, 1095-1121. doi: 10.1002/smj.275

Denrell, J., Fang, C., \& Winter, S. G. (2003). The economics of strategic opportunity. Strategic Management Journal, 24, 977-990. doi: 10.1002/smj. 341

Eisenhardt, K. M. \& Martin, J. A. (2000). Dynamic capabilities: What are they? Strategic Management Journal, 21, 1105-1121.

doi: 10.1002/1097-0266(200010/11)21:10/11<1105: : AID-SMJ 133>3.0.CO;2-E

Fernández, E., Montes, J. M., \& Vázquez, C. J. (2000). Typology and strategic analysis of intangible resources: A resource-based approach. Technovation, 20, 81-92. doi: 10.1016/S0166-4972(99)00115-7

Foss, N. J. (1997). Resources, firms, and strategies. Oxford: Oxford University Press.

Foss, N. J. (2007). Scientific progress in strategic management: The case of the resource-based view. International Journal of Learning and Intellectual Capital, 4(1/2), 29-46. doi:10.1504/IJLIC.2007.013821

Grant, R. M. (1991). The resource-based theory of competitive advantage: Implications for strategy formulation. California Management Review, 33(3), 114-135.

Hall, R. (1992). The strategic analysis of intangible resources. Strategic Management Journal, 13(2), 135-144. doi: 10.1002/smj.4250130205

Hunt, S. D. (1997). Resource-advantage theory: An evolutionary theory of competitive firm behaviour?. J ournal of Economic Issues, XXXI(1), 59-77. 
Hunt, S. D. (2000). A general theory of competition: resources, competences, productivity, economic growth. London: SAGE Publications.

Kraaijenbrink, J., Spender, J. C. \& Groen, A. J. (2010). The Resource-Based View: A Review and Assessment of Its Critiques. Journal of Management, 36 (1), 349372. doi: $10.1177 / 0149206309350775$

Madhavaram, S., \& Hunt, S. D. (2008). The service-dominant logic and a hierarchy of operant resources: Developing masterful operant resources and implications for marketing strategy. Journal of the Academy Marketing Science, 36(1), 6782. doi: 10.1007/s11747-007-0063-z

Mahoney, J. T., \& Pandian, J. R. (1992). The resource-based view within the conversation of strategic management. Strategic Management Journal, 13(5), 363-380. doi: 10.1002/smj. 4250130505

Miller, D., \& Shamsie, J. (1996). The Resource-Based View of the Firm in Two Environments: The Hollywood Film Studios from 1936 to 1965. The Academy of Management Journal, 39(3), 519-543. doi: 10.2307/256654

Nahapiet, J., \& Ghoshal, S. (1998). Social capital, intellectual capital, and the organizational advantage. Academy of Management Review, 23(2), 242-266. doi: $10.2307 / 259373$

Osigweh, C. A. B. (1989). Concept fallibility in organizational science. Academy of Management Review, 14(4), 579-594. doi: 10.2307/258560

Peteraf, M. A. (1993). The cornerstones of competitive advantage: A resourcebased view. Strategic Management J ournal, 14, 179-191. doi: $10.1002 /$ smj. 4250140303

Priem, R. L., \& Butler, J. E. (2001a). Is the resource-based "view" a useful perspective for strategic management research?. Academy of Management Review, 26(1), 22-40. doi:10.2307/259392

Priem, R. L., \& Butler, J. E. (2001b). Tautology in the resource-based view and the implications of externally determined resource value: Further comments. Academy of Management Review, 26(1), 57-65. doi: 10.2307/259394 
Schoenecker, T. S., \& Cooper, A. C. (1998). The Role of Firm Resources and Organizational Attributes in Determining Entry Timing: A Cross-Industry Study. Strategic Management J ournal, 19(2), 1127-1143.

doi: 10.1002/(SICI) 1097-0266(1998120) 19: 12<1127::AID-SMJ 7>3.0.CO;2-4

Seppänen, M., \& Mäkinen, S. (2007). Towards a classification of resources for the business model concept. International Journal of Management Concepts and Philosophy, 2(4), 389-404. doi: 10.1504/IJ MCP.2007.015133

Srivastava, R. K., Fahey, L., \& Christensen, H. K. (2001). The resource-based view and marketing: The role of market-based assets in gaining competitive advantage. J ournal of Management, 27, 777-802.

doi: $10.1177 / 014920630102700610$

Teece, D. J., Pisano, G., \& Shuen, A. (1997). Dynamic capabilities and strategic management. Strategic Management J ournal, 18(7), 509-533.

doi: 10.1002/(SICI)1097-0266(199708)18: 7<509: : AID-SMJ882>3.0.CO;2-Z

Teece, D. J. \& Pisano, G. (1994). The Dynamic Capabilities of firms: an introduction. Industrial and Corporate Change, 3, 537-556.

doi: 10.1093/icc/3.3.537-a

Tuomi, I. (1999). Data Is More Than Knowledge: Implications of the Reversed Knowledge Hierarchy for Knowledge Management and Organizational Memory. J ournal of Management Information Systems, 16(3), 103-117.

Wernerfelt, B. (1984). A resource-based view of the firm. Strategic Management Journal, 5(2), 171-180. doi: 10.1002/smj.4250050207

Winter, S. G. (2000). The satisficing principle in capability learning. Strategic Management J ournal, 21(10-11), 981-996.

doi: 10.1002/1097-0266(200010/11)21:10/11<981::AID-SMJ 125>3.0.CO;2-4

Winter, S. G. (2003). Understanding dynamic capabilities. Strategic Management J ournal, 24(10), 991-995. doi: 10.1002/smj.318 


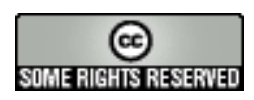

Article's contents are provided on an Attribution-Non Commercial 3.0 Creative commons license. Readers are allowed to copy, distribute and communicate article's contents, provided the author's and Journal of Industrial Engineering and Management's names are included. It must not be used for commercial purposes. To see the complete license contents, please visit http://creativecommons.org/licenses/by-nc/3.0/. 